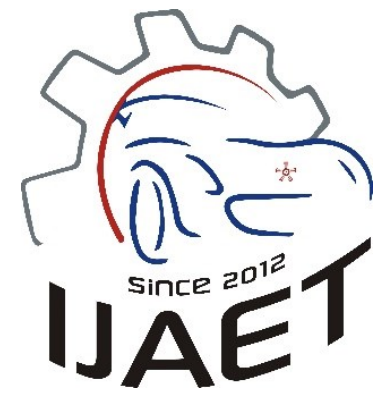

e-ISSN: 2146 - 9067

International Journal of Automotive

Engineering and Technologies

journal homepage:

https://dergipark.org.tr/en/pub/ijaet

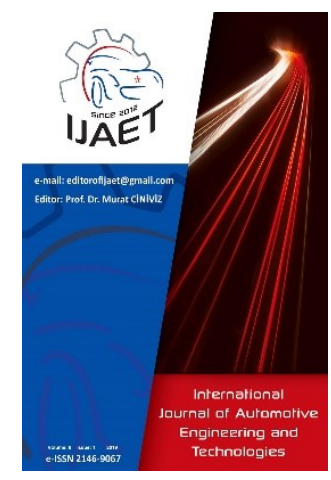

Original Research Article

\title{
Catalytic effect of metal based nanoparticles on emission and vibration analysis of diesel engine
}

\author{
Abdulkadir Yaşar ${ }^{1}$ *, Ali Keskin², Erdi Tosun ${ }^{3}$, Şafak Yıldızhan ${ }^{4}$ \\ 1,3 * Çukurova University, Ceyhan Engineering Faculty, Mechanical Eng. Dep., 01950 Adana, Turkey \\ ${ }^{2,4}$ Çukurova University, Engineering Faculty, Automotive Eng. Dep., 01330 Adana, Turkey
}

\section{ARTICLE INFO}

1 0000-0002-1548-2386

2 0000-0002-1089-3952

3 0000-0001-5733-2047

4 0000-0002-8981-9869

* Corresponding author ayasar@cu.edu.tr

Received: May 4, 2020

Accepted: June 2, 2020

Published by Editorial Board Members of IJAET

(C) This article is distributed by Turk Journal Park System under the CC 4.0 terms and conditions.

\begin{abstract}
In current study, exhaust emission, vibration and noise features of diesel engine with addition of metallic based nanoparticles into diesel fuels were investigated experimentally. Various nanoparticles called as silver (II) nitrate $\left(\mathrm{AgNO}_{3}\right)$, manganese (II) nitrate hydrate $\left(\mathrm{Mn}\left(\mathrm{NO}_{3}\right)_{2} . \quad \mathrm{xH}_{2} \mathrm{O}\right)$ and nickel(II) nitrate hexahydrate $\left(\mathrm{Ni}\left(\mathrm{NO}_{3}\right)_{2} \cdot 6 \mathrm{H}_{2} \mathrm{O}\right)$ were used as an additive to diesel fuel at $25 \mathrm{ppm}$ and $50 \mathrm{ppm}$ dosing level so as to obtain six different fuel samples. Diesel engine with air-cooled and a single cylinder were utilized for engine tests altering engine speed from 1200 to $2800 \mathrm{rpm}$ at the intervals of $400 \mathrm{rpm}$. The results demonstrated that of the nanoparticle addition did not remarkably affect the physicochemical features of the diesel test blends. But, the addition of nanoparticles slightly raised viscosity, cetane number and the heating value of test fuels especially, at the higher nanoparticle concentrations. In all experiments, with nanoparticle added blend fuels, $\mathrm{CO}, \mathrm{HC}, \mathrm{NO}_{\mathrm{x}}$ emission values and brake specific fuel consumption (BSFC) declined in parallel with the increase in nanoparticle concentration. In addition, it was shown that the Sound Pressure Level (SPL) and vibration characteristics of the engine block also decreased with increasing nanoparticle concentration of test fuels. As a result, $\mathrm{AgNO}_{3}$ addition to diesel fuel has an effective role in both reducing emission and vibration values and reducing BSFC values.
\end{abstract}

Keywords: Diesel engine, Nanoparticles, Exhaust emissions, Vibration, Noise.

\section{Introduction}

Diesel engines are utilized in various sectors like agriculture, transportation and industry due to lower specific fuel consumption, higher thermal output with high compression ratio, stability and low operational and maintenance expense. Despite such advantages, it increases environmental concerns in harmful emissions such as particulate matter and $\mathrm{NO}_{\mathrm{x}}$ causing serious health problems and environmental issue [1-3]. Therefore, researchers have concentrated their studies on improving fuel characteristics in order to achieve better fuel economy, engine performance and lower exhaust emissions.

There are various studies such as catalytic reduction, particulate filter and fuel additives into diesel fuel in order to control the harmful effects of emissions. Among them, metallic nanoparticles are widely utilized as a fuel 
additive in diesel fuels. Thanks to its high surface area, nanoparticles supply better combustion properties, high reactivity, reduced ignition delay and enhanced rate of heat transfer which enhance the fuel evaporation, thus, reduction in BSFC. It is confirmed that the additives with oxygen are also the appropriate choice for promoting the characteristics of diesel engine [4, 5]. An appropriate nanoparticles concentration also enhances fuel properties including viscosity, density, heating value, cetane number [6-9]. Whereas nanoparticles addition at higher concentrations can worsen the performance and result in increment of exhaust emissions [2-4].

Vibration and noise features play an important role on combustion characteristics of internal combustion engine. The engine vibration as a main source is resulted from the rotational and reciprocating components of the engine. The additional source of vibration and noise depends on fuel properties and combustion characteristics and injection features $[10,11]$. The vibration and noise could decrease operating the engine with nanoparticles in blend owing to better combustion efficiency [12]. The cetane number of the test fuel also affects combustion noise. The test fuels with nanoparticles have higher cetane number than conventional diesel leading to a decrement of a premixed combustion phase, thus decline in pressure increment rate and heat release rate, leading to reduction of combustion vibration and noise [13].

Many experimental study have been performed in order to evaluate the additional nanoparticle effect blended diesel fuel in terms of determining optimal dosage level and decreasing emission and vibration.

Saraee et al. [14] reported that silver nanoparticles enhanced the heat transfer to fuel and reduced the ignition delay resulting in significant decrement of emissions. The promotion of performance and decline in emissions were due to rise in higher calorific value and the thermal conductivity of nanoparticles blended fuels. It was noted that silver oxide addition enhances the cylinder pressure and heat release rate (HRR) by improving the fuel atomization, decreasing the ignition delay and hence escalating the combustion process [15]. Guru et al. [8] studied on enhancement of diesel fuel properties with $\mathrm{CaO}, \mathrm{MgO}, \mathrm{MnO}_{2}$ and $\mathrm{CuO}$ nanoparticle addition. They revealed that test fuels having high cetane number had smaller premixed fuel portions and less NO emissions for the same brake mean effective pressure in comparison with lower cetane number of diesel fuel. Manganese oxide and copper oxide nanoparticle addition into diesel fuel were studied by Lenin et al. [16]. They reported that $\mathrm{CO}$ and $\mathrm{NO}_{\mathrm{x}}$ emissions diminished with manganese addition into nude diesel fuel. The metallic additives with $\mathrm{MnO}_{2}$ and $\mathrm{NiO}$ was mixed into biodiesel at various rates in order to compose blend fuels by Keskin et al. [17]. They stated that emissions of $\mathrm{NO}_{\mathrm{x}}$ were observed to be comparatively higher with $\mathrm{Mn}$ addition as against $\mathrm{Ni}$ additives. They put forward that higher $\mathrm{NO}_{\mathrm{x}}$ value is resulted from $\mathrm{Mn}$ additives which have more catalyst effect on combustion bringing about increment of the maximum temperature. Srinidhi et al. [18] studied the influence of nickel oxide nanoparticle added biodiesel on CI engine performance at various fuel injection timing. They observed a decrease in $\mathrm{HC}$ and $\mathrm{CO}$ emissions with $\mathrm{NiO}$ particle addition. Ozgur et al. [19] revealed addition effect of various metal oxide nanoparticles considering $\mathrm{NO}_{\mathrm{x}}$ emissions of diesel engine. They demonstrated that the nanoparticle addition caused a reduction in $\mathrm{NO}_{\mathrm{x}}$ emissions. Yaşar et al. [12] searched engine exhaust emissions, vibration and noise characteristics fuelled by various metal oxide nanoparticles in base diesel fuel. They concluded that both exhaust emissions such as $\mathrm{CO}, \mathrm{HC}$ except for $\mathrm{NO}_{\mathrm{x}}$ as well as vibration and sound values were decreased at higher concentration of nanoparticles. Uludamar et al. [20] studied the influence of different biodiesel blends on vibration and noise characteristics of the CI engine. They also reported that the vibration and noise levels of engine were minimized with increase in blend ratio.

While many researchers have focused their studies on only performance and pollutant characteristics of nanoparticles. It is also vital important to choose optimal dosage level of nanoparticle blended fuels and nanoparticle types with high catalytic activity in order to control vibration and sound levels arisen from diesel engine. Accordingly, this study concentrates on the effect of nanoparticle blend 
fuels such as silver nitrate $\left(\mathrm{AgNO}_{3}\right)$, nickel (II) nitrate hexahydrate $\left(\mathrm{Ni}\left(\mathrm{NO}_{3}\right)_{2} \cdot 6 \mathrm{H}_{2} \mathrm{O}\right)$ and manganese (II) nitrate hydrate $\left(\mathrm{Mn}\left(\mathrm{NO}_{3}\right)_{2} \cdot \mathrm{xH}_{2} \mathrm{O}\right)$ on performance, exhaust emission, noise and vibration levels of diesel engine.

\section{Material and methods}

Determination of test fuel properties and engine tests were implemented at Automotive Engineering Laboratories of Cukurova University.

\subsection{Preparation of test fuels}

Nanoparticles such as silver (II) nitrate $\left(\mathrm{AgNO}_{3}\right)$, manganese (II) nitrate hydrate $\left(\mathrm{Mn}\left(\mathrm{NO}_{3}\right)_{2} \cdot \mathrm{xH}_{2} \mathrm{O}\right.$ and nickel(II) nitrate hexahydrate $\left(\mathrm{Ni}\left(\mathrm{NO}_{3}\right)_{2} .6 \mathrm{H}_{2} \mathrm{O}\right)$ were supplied in powder form from Merck brand. Nanoparticles blended diesel fuels were obtained as $25 \mathrm{ppm}$ and $50 \mathrm{ppm}$ dosing levels by using the nanoparticle additives as stated above. Test fuels were addressed as DNi25 (Diesel $+25 \mathrm{ppm}$ $\left.\mathrm{Ni}\left(\mathrm{NO}_{3}\right)_{2} .6 \mathrm{H}_{2} \mathrm{O}\right), \quad \mathrm{DNi} 50 \quad($ Diesel $+50 \mathrm{ppm}$ $\left.\mathrm{Ni}\left(\mathrm{NO}_{3}\right)_{2} \cdot 6 \mathrm{H}_{2} \mathrm{O}\right), \quad \mathrm{DMn} 25$ (Diesel+25 ppm $\left.\mathrm{Mn}\left(\mathrm{NO}_{3}\right)_{2} \cdot \mathrm{xH}_{2} \mathrm{O}\right), \quad \mathrm{DMn} 50 \quad($ Diesel+50 ppm $\left.\mathrm{Mn}\left(\mathrm{NO}_{3}\right)_{2} \cdot \mathrm{xH}_{2} 0\right)$, DAg25 (Diesel+25 ppm $\mathrm{AgNO}_{3}$ ) and DAg50 (Diesel+50 ppm $\mathrm{AgNO}_{3}$ ).

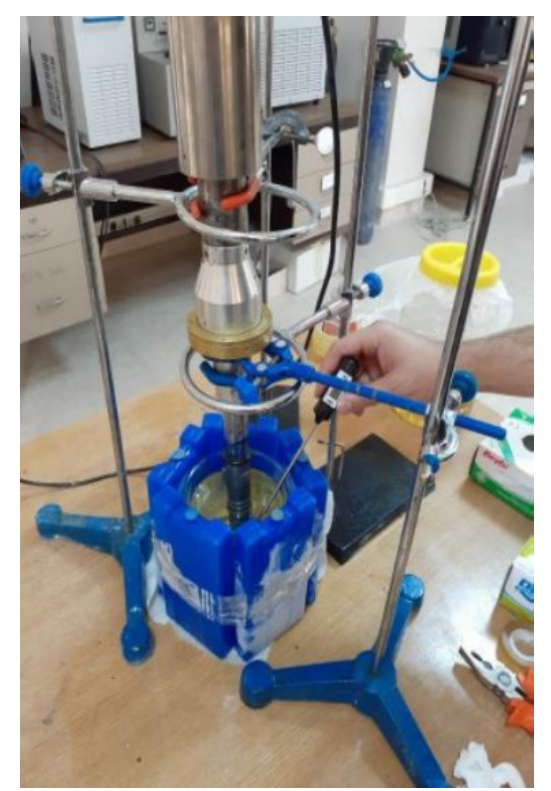

Fig. 1. Sonic Ultrasonicator

It is important to form stable nanofluids with suitable properties. Different methods were also proposed to make the stability better in nanofluids such as Stirring, Shear homogenization, Sonication and various active agents [2]. In this study, ultrasonic processor
(Sonic Vibra-Cell VC 750 model) having 40\% amplitude was utilized in order to spread the nanoparticle additives into diesel fuel properly as illustrated in Fig. 1. Therefore, engine experiments were conducted in a short time after the mixing to avoid agglomerate of the nanoparticles. In this way, homogeneously prepared fuels do not cause any plugging in the injection system.

The amount of nanoparticle was gauged with a sensitive electronic stability with a $0.0001 \mathrm{~g}$ sensitivity. The ultrasonic processor properties, brand and accuracy of the other devices used for fuel analyzing were also shown in reference [12]. EN 590 standard was taken for reference in order to compare analyzed blend fuels.

\subsection{Experimental setup and test procedure}

In this work, diesel engine with a single cylinder (air-cooled) and an AC Induction Servo Motor dynamometer were utilized to assess emissions properties and vibrational effect of the test fuels at full load conditions. Technical features of the engine and dynamometer were shown in Tables $1-2$, respectively. Schematic outline of the test rig was also given in Fig. 2. All tests were carried out under steady state conditions. Before starting the experiments, engine was operated $15 \mathrm{~min}$ to for stable operating conditions. Engine speed was altered ranging from 1200 to $2800 \mathrm{rpm}$ at $400 \mathrm{rpm}$ intervals. Firstly, the engine was initially operated with diesel fuel to compare with other test fuel results. Tests were duplicated three times for each fuel and the average of measurements was registered in similar conditions. Emission measurements were performed by exhaust gas analyzer (MRU DELTA 1600-V) which was calibrated before measurements. The technical properties of the exhaust gas device are given in Table 3.

Table 1. Technical specifications of engine

\begin{tabular}{ll}
\hline Brand & Thorq \\
\hline Type & RF150 \\
Number of Cylinder & 1 \\
Volume & $0.638 \mathrm{~L}$ \\
Bore/Stroke & $95 \mathrm{~mm} / 90 \mathrm{~mm}$ \\
Compression Ratio & $17: 1$ \\
Maximum Power/rpm & $11 \mathrm{~kW} / 3000 \mathrm{rpm}$ \\
Maximum Torque/rpm & $3.5 \mathrm{~kg} \cdot \mathrm{m} / 1800 \mathrm{rpm}$ \\
Specific Fuel & $255 \mathrm{~g} / \mathrm{kWh}$ \\
Consumption/1800 rpm & $57 \mathrm{~kg}$ \\
Weight & Air \\
Cooling & \\
\hline
\end{tabular}


Table 2. Technical properties of dynamometer

\begin{tabular}{ll}
\hline Type & $\begin{array}{l}\text { AC Induction Servo Motor } \\
(\mathbf{2 6} \mathbf{k W})\end{array}$ \\
\hline Maximum rpm & $9000 \mathrm{rpm}$ \\
Capacity & $0-3000 \mathrm{rpm}$ 0-83 Nm \\
Sensitivity & $\pm 3000 \mathrm{rpm}$ Constant Power \\
Load Cell & S Type Load Cell \\
Cooling & Forced Air \\
\hline
\end{tabular}

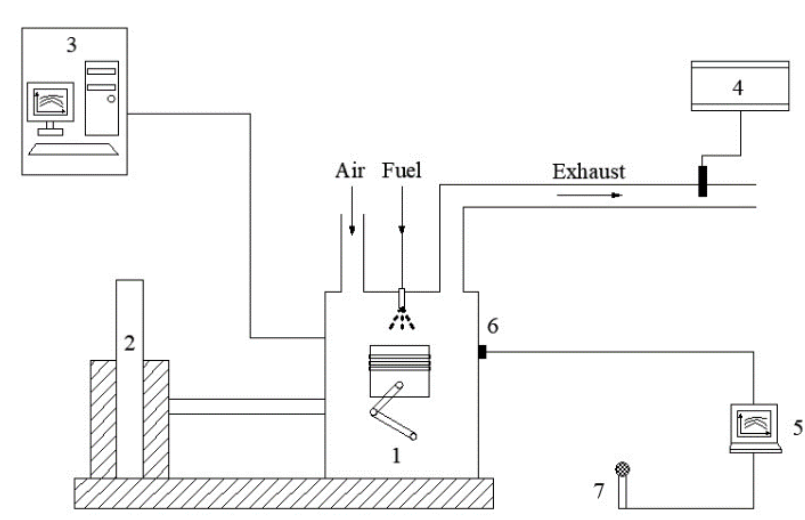

Fig. 2. Test-rig (1-Diesel Engine 2-AC Dynamometer 3Performance Measuring System 4-Emission Device 5-

Noise and Vibration Measuring System 6-Accelerometer 7-Microphone)

Table 3. Measurement values for emission device with ranges, accuracy and resolution

\begin{tabular}{ll}
\hline Specification & $\begin{array}{l}\text { Ranges, accuracy and } \\
\text { resolution }\end{array}$ \\
\hline $\mathrm{CO}$ & $0-10 \%$ \\
$\mathrm{CO}_{2}$ & $0-20 \%$ \\
$\mathrm{HC}$ & $0-20000 \mathrm{ppm}$ \\
$\mathrm{O}_{2}$ & $0-22 \%$ \\
$\mathrm{NO}$ & $0-4000 \mathrm{ppm}$ \\
$\mathrm{NO}_{2}$ & $0-1000 \mathrm{ppm}$ \\
Lambda & $0-9,99$ \\
Accuracy & According to OIML-class 1 \\
Ambient Temperature & $5{ }^{\circ} \mathrm{C}-45^{\circ} \mathrm{C}$ \\
Exhaust Gas & Max $650{ }^{\circ} \mathrm{C}$ \\
\hline
\end{tabular}

\subsection{Measurement system for accelerometer} and microphone

A universal portable measuring system supplied from SINUS Messtechnik GmbH was employed to record the acoustic and vibration data of the engine by means of Triaxial ICP_accelerometer from PCB Piezoelectronics with $\overline{1} .02 \mathrm{mV} /\left(\mathrm{m} / \mathrm{s}^{2}\right)$ of sensitivity and $\pm 4905 \mathrm{~m} / \mathrm{s}^{2}$ of measurement range. For vibration measurements, the accelerometer having three orthogonal axes was mounted on engine body. A microphone was used to register the SPL values of the engine. GRAS half-inch free field standard microphone set was used so as to measure SPL of engine. Sensivity, frequency range and dynamic range of microphone set are $50 \mathrm{mV} / \mathrm{Pa}, 3.15 \mathrm{~Hz}-20$
$\mathrm{kHz}$ and 17-149 $\mathrm{dB}(\mathrm{A})$, respectively. To make sound measurements more precise, the test chamber and circumference of the engine dynamometer were isolated with sound absorbers. Root Mean Square (RMS) value was considered so as to obtain the intensity of the engine vibration. Time history of the wave is used for the measurement of amplitudes. RMS values were obtained with the help of Eq.(1), analysis of atotal and SPL values were implemented so as to compare engine vibration and noise features. Eq. 1 and 2 were used to calculate the atotal.

$a_{w}=\sqrt{\frac{1}{T} \int_{0}^{T} a_{w}^{2}(t) \mathrm{dt}}$

Where, $\mathrm{a}_{\text {total }}$ and $\mathrm{T}$ denote total acceleration $\left(\mathrm{m} / \mathrm{s}^{2}\right)$ and reading time, respectively.

Total vibration acceleration $\left(a_{\text {total }}\right)$ of the diesel engine was calculated from equation 2.

$\sqrt{a_{\text {total }}=}$

Acceleration in all axes were denoted as $\mathrm{a}_{\mathrm{vertical}}$, $\mathrm{a}_{\text {lateral }}$ and alongitudinal, respectively.

\section{Result and discussion}

The following section covers the conclusions of emissions, vibration properties, fuel features and BSFC for diesel fuel, other test fuels with nanoparticle additives.

\subsection{Test fuel properties}

Physicochemical properties of the test fuels like viscosity, Cetane number, density, heating value, pour point, flash point and copper strip corrosion were measured as shown in Table 4. It was observed that all properties of test fuels are in accordance with EN590 standards.

With the nanoparticle addition into diesel fuel, there were no considerable change in physicochemical properties of the test fuels, but slight increase in viscosity, the heating value and cetane number of blend fuels were observed at the higher concentration of nanoparticles.

\subsection{Brake specific fuel consumption}

BSFC is a noteworthy indicator of engine performance and presents knowledge about how much the fuel provided to the engine is converted to work [2]. Fig. 3. Shows variation 
Table 4. Test fuel properties

\begin{tabular}{lcccccccc}
\hline Fuel & $\begin{array}{c}\text { Cetane } \\
\text { number }\end{array}$ & $\begin{array}{c}\text { Density } \\
\left(\mathbf{k g} / \mathbf{m}^{\mathbf{3}} \mathbf{)}\right) \\
\mathbf{1 5}^{\circ} \mathbf{C}\end{array}$ & $\begin{array}{c}\text { Viscosity } \\
\left(\mathbf{m m}^{2} / \mathbf{s}\right) \mathbf{a t} \\
\mathbf{4 0} \mathbf{C}\end{array}$ & $\begin{array}{c}\text { Heating } \\
\text { value } \\
\mathbf{M J} / \mathbf{k g}\end{array}$ & $\begin{array}{c}\text { Pour } \\
\text { point } \\
\left({ }^{\mathbf{}} \mathbf{C}\right)\end{array}$ & $\begin{array}{c}\text { Cloud } \\
\text { point } \\
\left({ }^{\circ} \mathbf{C}\right)\end{array}$ & $\begin{array}{c}\text { Flash } \\
\text { point } \\
\left({ }^{\circ} \mathbf{C}\right)\end{array}$ & $\begin{array}{c}\text { Copper } \\
\text { strip } \\
\text { corrosion }\end{array}$ \\
\hline EN590 & min 51 & $820-840$ & $2-4.5$ & - & - & - & min 55 & $1 \mathrm{a}$ \\
Diesel & 56.277 & 841.1 & 2.701 & 44.66 & -24 & -3 & 90 & $1 \mathrm{a}$ \\
DNi25 & 57.327 & 841.3 & 2.732 & 45.18 & -26 & -3 & 80.5 & $1 \mathrm{a}$ \\
DNi50 & 57.485 & 841.5 & 2.765 & 45.22 & -24 & -3 & 78.5 & $1 \mathrm{a}$ \\
DAg25 & 57.415 & 841.9 & 2.822 & 45.19 & -25 & -3 & 84.5 & $1 \mathrm{a}$ \\
DAg50 & 57.687 & 842.1 & 2.843 & 45.25 & -24 & -2 & 80 & $1 \mathrm{a}$ \\
DMn25 & 57.287 & 841.6 & 2.792 & 45.21 & -25 & -3 & 76 & $1 \mathrm{a}$ \\
DMn50 & 57.445 & 841.9 & 2.814 & 45.37 & -24 & -3 & 80 & $1 \mathrm{a}$ \\
\hline
\end{tabular}

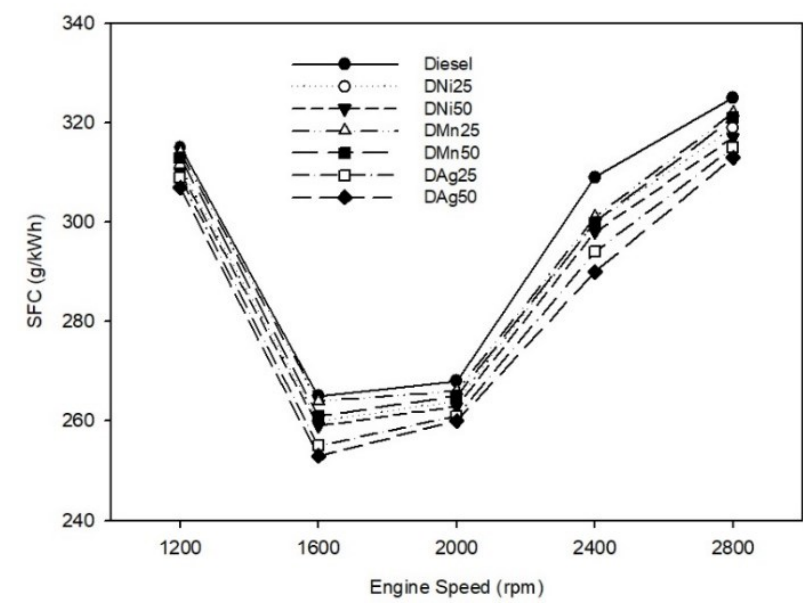

Fig. 3. Change in BSFC with engine speed

of BSFC values versus engine speed. BSFC values for nanoparticle and diesel fuel blends decreased by $1.88 \%, 2.36 \%, 1.01 \%, 1.48 \%$, $3.23 \%$ and $3.98 \%$ in relation to nude diesel for DNi25, DNi50, DMn25, DMN50, DAg25 and DAg50, respectively. Of all the tests, the maximum reduction rate was achieved in DAg50 with $6.55 \%$ at $2400 \mathrm{rpm}$. This is due to the fact that $\mathrm{AgNO}_{3}$ nanoparticles in the combustion chamber provide extra oxygen, enhanced oxidation rate and a decline in ignition temperature for preferable combustion characteristics and caused rise in brake thermal efficiency and lessen in BSFC. These findings are in harmony with the studies performed by some authors [9, 12, 17, 21].

\subsection{CO Emissions}

The primary reason of $\mathrm{CO}$ formation is owing to the incomplete burning of charge in the combustion chamber [19]. The change in CO emissions according to engine speed is illustrated in Fig.4.
From the Fig.4, mean reduction in the $\mathrm{CO}$ emission values was found as $2.68 \%$ with DNi25, 3.46\% with DNi50, 1\% with DMn25, $3.94 \%$ with DMn50, $13.39 \%$ with DAg25 and $17.06 \%$ with DAg50. Maximum decrement value is $18.43 \%$ with DAg50 at $2800 \mathrm{rpm}$. This can be attributed that $\mathrm{AgNO}_{3}$ nanoparticles are uniformly spread thanks to catalytic activity of them, which enhances the air-fuel mixing and desirable combustion. Therefore, complete combustion supports the oxidization of their intermediate products. This complete combustion enables carbon monoxide to be converted to carbon dioxide. This situation was also noted that by some researchers [1, 22-23].

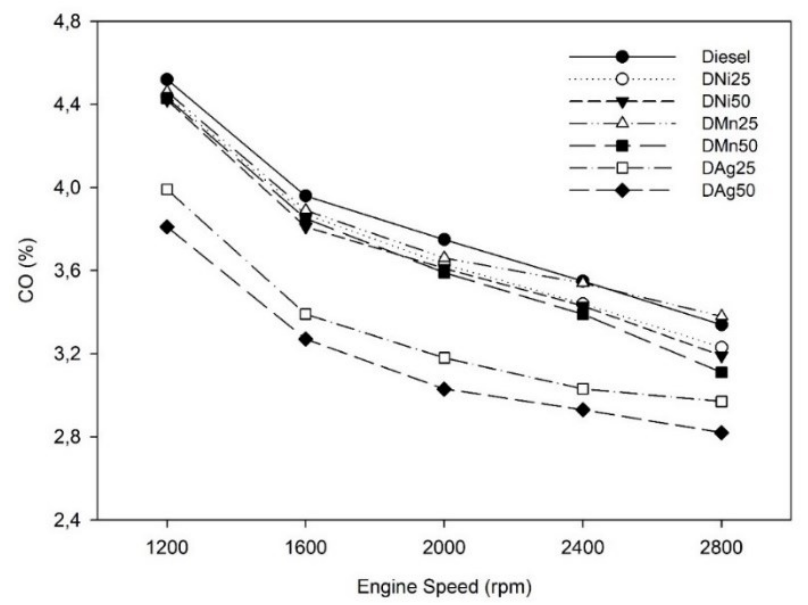

Fig.4. Change in $\mathrm{CO}$ emissions with engine speed

\subsection{HC emissions}

Higher level of hydrocarbon emissions is due to incomplete combustion resulting from distorted flame propagation, low store temperature, less injection timing and pressure in the cylinder [24]. The effect of nanoparticles on $\mathrm{HC}$ emissions is illustrated in Fig.5. The average 
reduction of blend fuels in $\mathrm{HC}$ emissions are $11.26 \%, 15.59 \%, 5.19 \%, 11.43 \%, 19.93 \%$ and $25.99 \%$ for DNi25, DNi50, DMn25, DMN50, DAg25 and DAg50, respectively compared with conventional diesel fuel. From the results, it was introduced that silver nitrate has the stronger effect in decreasing $\mathrm{HC}$ emissions. Reduction in $\mathrm{HC}$ emissions can be resulted from the higher evaporation rate and catalytic oxidation. These indications are good agreement with the literature studies [1-4,12,17].

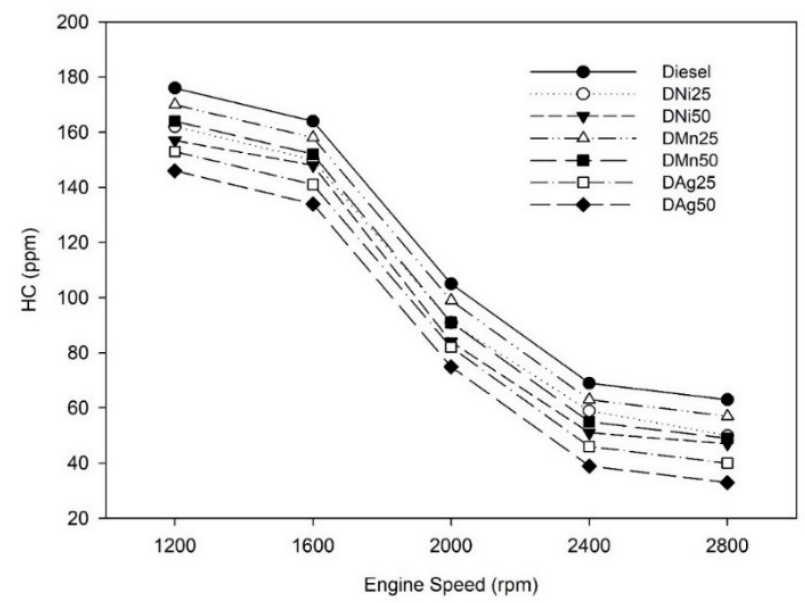

Fig.5. Effect of nanoparticles on HC emissions

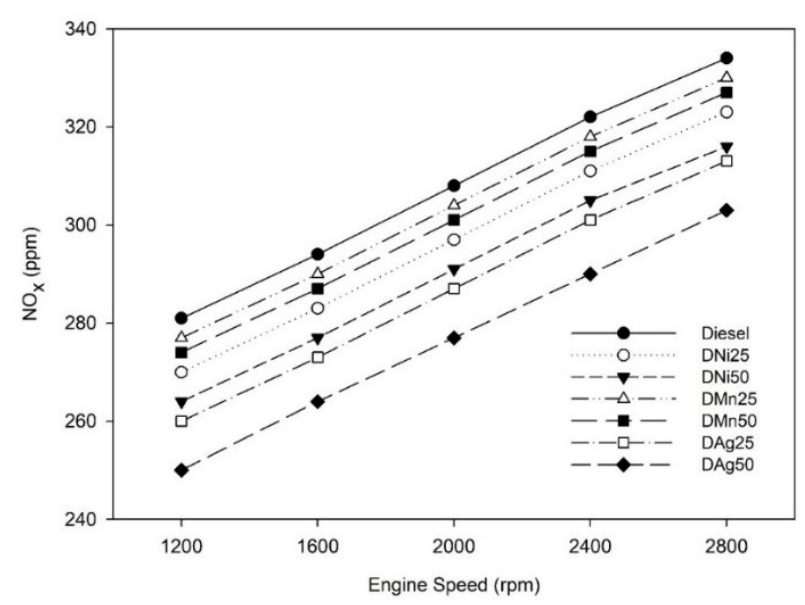

Fig.6. Effect of nanoparticles on $\mathrm{NO}_{\mathrm{x}}$ emissions

\subsection{NOx emissions}

$\mathrm{NO}_{\mathrm{x}}$ formation is derived from many factors which are fuel properties, engine design parameters, combustion temperature, reaction time and engine operating conditions [2, 25]. Effect of nanoparticles on $\mathrm{NO}_{\mathrm{x}}$ emissions is given in Fig.6. As depicted in Fig.6, average reduction $\mathrm{NO}_{\mathrm{x}}$ emissions of the $\mathrm{DNi} 25, \mathrm{DNi} 50$, DMn25, DMN50, DAg25 and DAg50 test fuels were observed as $3.57 \%, 5.58 \%, 1.29 \%, 2.27 \%$, $6.82 \%$ and $10.07 \%$, respectively. Nitrogen oxide emissions are observed to decrease when added nanoparticles to diesel fuel depending higher dosage level of the nanoparticle. The greatest reduction of $\mathrm{NO}_{\mathrm{x}}$ emissions was found to be $10.23 \%$ for DAg50 at $2800 \mathrm{rpm}$. $\mathrm{NO}_{\mathrm{x}}$ emission values are lower with the $\mathrm{AgNO}_{3}$ additives in comparison with $\mathrm{Ni}$ and $\mathrm{Mn}$ additives in blend. The reason for this reduction can be considered as nanoparticles having higher thermal conductivity and test fuels with higher cetane number. These observations are compatible with the studies of some researchers $[4,8]$.

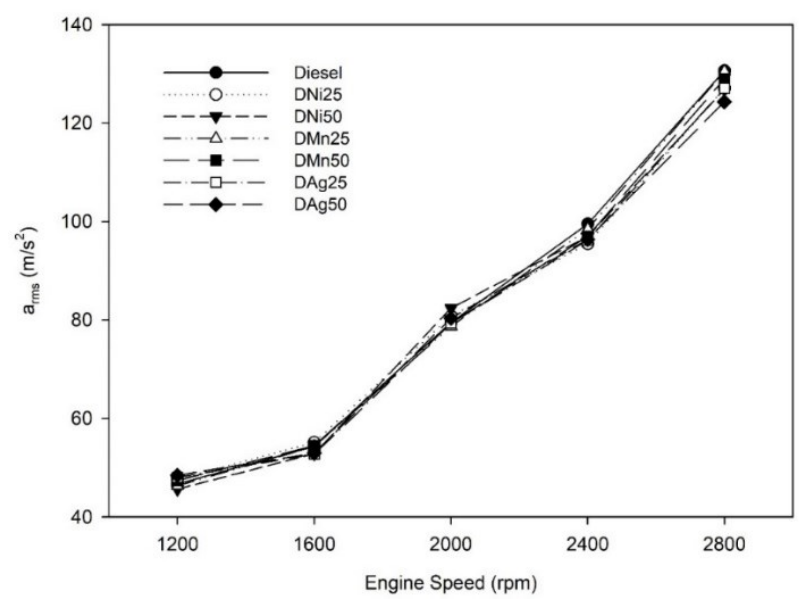

Fig.7. Effect of engine speed on vibration acceleration

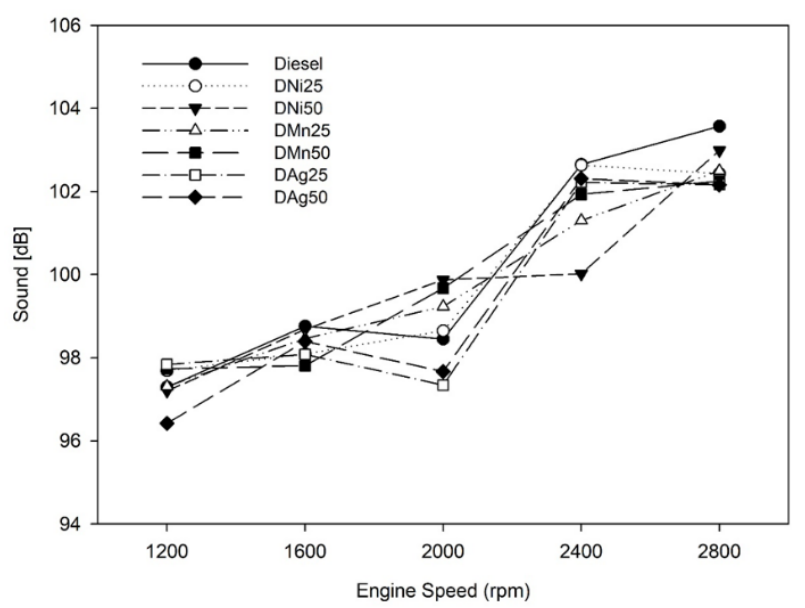

Fig.8. Effect of engine speed on sound pressure level

\subsection{Engine vibration and noise characteristics}

The main source caused by engine vibration is due to the rotation and piston components of the engine. The additional source of vibration and noise is directly related with fuel type and injectors $[10,11]$. It was demonstrated that the nanoparticle addition to fuels decreased the vibration and noise levels of the engine thanks to better combustion efficiency [12]. Fig.7. represents the variation of engine speed with 
vibration acceleration for test fuels. From the tests, mean reduction of engine vibration is $1.15 \%, 1.49 \%, 0.58 \%, 0.85 \%, 1.78 \%$ and $2.01 \%$ for DNi25, DNi50, DMn25, DMN50, DAg25 and DAg50, respectively when compared with conventional diesel fuel. For all test fuels, vibration values of engine decreased slightly for nanoparticle fuel blends compared to nude diesel fuel. Maximum reduction was obtained as $5.08 \%$ for DAg50 at $2800 \mathrm{rpm}$. The variation of engine speed on SPL for test fuels is depicted in Fig.8. Average decrement rate of SPL was determined as $0.30 \%$ with $\mathrm{DNi} 25,0.39 \%$ with DNi50, $0.24 \%$ with DMn25, 0.26\% with DMn50, 0.61\% with DAg25 and $0.75 \%$ with DAg50. Maximum decline of SPL of the engine was also observed as 1.38 for DAg50 at 2800 rpm.

The results revealed that both engine vibration as well noise levels were decreased by raise in higher dosage level of nanoparticles. Some researchers also reported that there was similar correlation between noise vibration results in the condition of compression ignition engines [12, 26].

\section{Conclusions}

The paper primarily demonstrates the effect of metallic based nanoparticles into diesel fuel on emissions and vibration characteristics of diesel engine. The results obtained from this study are given below.

- No significant change was observed in physicochemical properties of test fuels with nanoparticle addition into diesel fuel. Nevertheless, there is slight rise in viscosity, the heating value and cetane number of blend fuels.

- BSFC declined with the addition of nanoparticles for whole test fuels. Maximum decrement was observed as 3.98\% for DAg50 at $2400 \mathrm{rpm}$ as compared conventional diesel fuel. This could be attributed that $\mathrm{AgNO}_{3}$ nanoparticles in the combustion chamber provide extra oxygen, enhance in oxidation rate and decline in ignition temperature for preferable combustion characteristics and results in the rise of brake thermal efficiency and decrement in BSFC.

- Maximum decline in $\mathrm{CO}, \mathrm{HC}$ and $\mathrm{NO}_{\mathrm{x}}$ emissions were observed as $13.39 \%, 25.99 \%$ and $10.07 \%$, respectively for DAg50 at 2800 $\mathrm{rpm}$. This is due to the fact that nanoparticles are homogeneously spread owing to catalytic activity of nanoparticles, which promotes the air-fuel mixing and desirable combustion. $\mathrm{NO}_{\mathrm{x}}$ emissions are reduced, possibly owing to the higher thermal conductivity of the nanoparticles, and thus, lower the combustion gas temperature.

- Engine vibration and sound pressure levels escalated with the increment of engine speed. Nevertheless, those levels of diesel engine were decreased with raise in higher dosage level of nanoparticles when checked with diesel fuel. It has also been observed that $\mathrm{AgNO}_{3}$ has a positive effect on the vibration and sound level among the test fuels used.

In conclusion, silver nitrate nanoparticle with diesel fuel blend has a stronger effect in decreasing BSFC, engine emissions and vibration characteristics of engine compared to manganese (II) nitrate hydrate and nickel (II) nitrate hexahydrate added to diesel fuel.

In future works, more experimental study is necessary to meet the deficiency about the combined effects of nanoparticles in terms of optimal dosage level and reduction of vibrationsound level.

\section{Acknowledgement}

The authors would like to thank the Çukurova University Scientific Research Project Coordination (FBA-2019 - 11937) for financial support.

\section{References}

1. S. Kumar, P. Dinesha, C.M. Ajay, P. Kabbur, Combined effect of oxygenated liquid and metal oxide nanoparticle fuel additives on the combustion characteristics of a biodiesel engine operated with higher blend percentages. Energy 197, 117194, 2020.

2. V. Saxena, N. Kumar, V.K.Saxena, A comprehensive review on combustion and stability aspects of metal nanoparticles and its additive effect on diesel and biodiesel fuelled C.I. engine. Renewable and Sustainable Energy Reviews 70, 563-588, 2017.

3. S. Khan, Y. Dewang, J. Raghuwanshi, A. Shrivastava, V. Sharma, Nanoparticles as fuel additive for improving performance and reducing exhaust emissions of internal combustion engines. International Journal of 
Environmental Analytical Chemistry. https://doi.org/10.1080/03067319.2020.172281

0 .

4. K. Nanthagopal, R.S Kishna, A.E. Atabani, A.H. Al-Muhtaseb, A compressive review on the effects of alcohols and nanoparticles as an oxygenated enhancer in compression ignition engine. Energy Conversion and Management 203, 112244 , 2020.

5. J.J. Granier, M.L. Pantoya, Laser ignition of nanocomposite thermites. Combustion and Flame 138, 373-383, 2004.

6. M.V. Kumar, A.V. Babu, P.R. Kumar, Influence of metal-based cerium oxide nanoparticle additive on performance, combustion, and emissions with biodiesel in diesel engine. Environmental Science and Pollution Research 26, 7651-7664, 2019.

7. H.K. Patel, S. Kumar, Experimental analysis on performance of diesel engine using mixture of diesel and bio-diesel as a working fuel with Aluminum Oxide nanoparticle additive. Thermal Science and Engineering Progress 4, 252-258, 2017.

8. M. Guru, U. Karakaya, D. Altıparmak, A. Alıcilar, Improvement of Diesel fuel properties by using additives. Energy Conversion and Management 43, 1021-1025, 2002.

9. S Gumus, Ozcan H, Ozbey M, Topaloglu B. Aluminum oxide and copper oxide nanodiesel fuel properties and usage in a compression ignition engine. Fuel 163, 80-87, 2016.

10. A.A. Taghizadeh, B. Ghobadian, H.T. Tavakoli, S. Mohtasebi, S. Saeid, S. Mohtasebi, Vibration analysis of a diesel engine using biodiesel and petro-diesel fuel blends. Fuel 102, 414-422, 2012.

11. T.A. Ahmad, R.A. Abbas, the effect of added ethanol to diesel fuel on performance, vibration, combustion and knocking of a CI engine. Fuel 185, 718-733, 2016.

12. Yaşar, A. Keskin, Ş. Yıldızhan, E. Uludamar, Emission and vibration analysis of diesel engine fuelled diesel fuel containing metallic based nanoparticles. Fuel 239, 12241230, 2019.
13. Koder, P. Schwanzer, F. Zacherl, H.P. Rabl, W. Mayer, G. Gruber, T. Dotzer, Combustion and emission characteristics of a 2.2 L common-rail diesel engine fueled with jatropha oil, soybean oil, and diesel fuel at various EGR-rates. Fuel 228, 23-29, 2018.

14. H.S. Saraee, S. Jafarmadar, H. Taghavifar, S.J. Ashrafi, Reduction of emissions and fuel consumption in a compression ignition engine using nanoparticles. International Journal of Environmental Science and Technology 12, 2245-2252, 2015.

15. Y. Devarajan, A. Mahalingam, D.B. Munuswamy, T. Arunkumar, Combustion, performance, and emission study of a research diesel engine fueled with palm oil biodiesel and its additive. Energy Fuels 32, 8447-8452, 2018. 16. M.A. Lenin, M.R. Swaminathan, G. Kumaresan, Performance and emission characteristics of a DI diesel engine with a nanofuel additive. Fuel 109, 362-365, 2013.

17. Keskin, M. Guru, D. Altiparmak, Biodiesel production from tall oil synthesized $\mathrm{Mn}$ and Ni based additives: effects of the additives on fuel consumption and emissions. Fuel 86, 1139-1143, 2007.

18. P.C. Srinidhi, A. Madhusudhan, S.V. Channapattana, Effect of $\mathrm{NiO}$ nanoparticles on performance and emission characteristics at various injection timings using biodiesel-diesel blends. Fuel 235, 185-193, 2019.

19. T. Ozgur, G. Tuccar, E. Uludamar, A.C. Yilmaz, C. Gungor, M. Ozcanli, H. Serin, K. Aydin, Effect of nanoparticle additives on $\mathrm{NO}_{\mathrm{x}}$ emissions of diesel fuelled compression ignition engine. International Journal of Global Warming 4, 487-98, 2015.

20. E. Uludamar, E. Tosun, K. Aydin, Experimental and regression analysis of noise and vibration of a compression ignition engine fuelled with various biodiesels. Fuel 177, 32633, 2016.

21. V.A.M. Selvan, R.B. Anand, M. Udayakumar, Effects of cerium oxide nanoparticle addition in diesel and dieselbiodiesel-ethanol blends on the performance and emission characteristics of a $\mathrm{CI}$ engine. 
ARPN Journal of Engineering and Applied Sciences 4, 1-6, 2009.

22. H.S. Saraee, S. Jafarmadar, E. AlizadehHaghighi, S.J. Ashrafi, Experimental investigation of pollution and fuel consumption on a CI engine operated on alumina nanoparticles-Diesel fuel with the aid of artificial neural network. Environmental Progress and Sustainable Energy 35, 540-546, 2016.

23. S. Nayak, V.B. Shet, C.V. Rao, K. Joshi, Performance evaluation and emission characteristics of a 4 stroke diesel engine using green synthesized silver nanoparticles blended biodiesel. Materials Today: Proceedings 5, 7889-7897, 2018.

24. C.D. Rakopoulos, K.A. Antonopoulos, D.C. Rakopoulos, D.T. Hountalas, Multi-zone modeling of combustion and emissions formation in DI diesel engine operating on ethanol-diesel fuel blends. Energy Conversion and Management 49, 625-643, 2008.

25. D. Khatri, R. Goyal, A. Darad, A. Jain, S. Rawat, A. Khan and A.T. Johnson, Investigations for the optimal combination of zinc oxide nanoparticle-diesel fuel with optimal compression ratio for improving performance and reducing the emission features of variable compression ratio diesel engine. Clean Technologies and Environmental Policy 21, 1485-1498, 2019.

26. Patel, N. Tiwari, A.K. Agarwal, Experimental investigations of Soybean and Rapeseed SVO and biodiesels on engine noise, vibrations, and engine characteristics. Fuel 238, 86-97, 2019. 